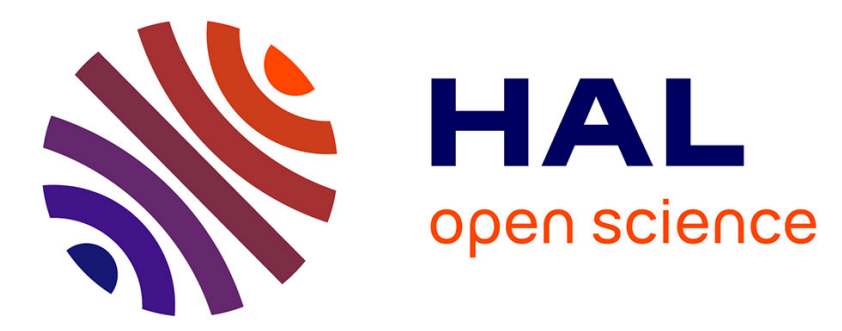

\title{
Prevalence of Anaplasma phagocytophilum in small rodents in France
}

\author{
A. Chastagner, M. Moinet, Grégoire Perez, E. Roy, Karen Mccoy, Olivier \\ Plantard, A. Agoulon, S. Bastian, Alain Butet, Yann Rantier, et al.
}

\section{- To cite this version:}

A. Chastagner, M. Moinet, Grégoire Perez, E. Roy, Karen Mccoy, et al.. Prevalence of Anaplasma phagocytophilum in small rodents in France. Ticks and Tick-borne Diseases, 2016, 7 (5), pp.988-991. 10.1016/j.ttbdis.2016.05.005 . hal-01328852

\section{HAL Id: hal-01328852}

\section{https://hal-univ-rennes1.archives-ouvertes.fr/hal-01328852}

Submitted on 3 Oct 2016

HAL is a multi-disciplinary open access archive for the deposit and dissemination of scientific research documents, whether they are published or not. The documents may come from teaching and research institutions in France or abroad, or from public or private research centers.
L'archive ouverte pluridisciplinaire HAL, est destinée au dépôt et à la diffusion de documents scientifiques de niveau recherche, publiés ou non, émanant des établissements d'enseignement et de recherche français ou étrangers, des laboratoires publics ou privés. 
2

3 Chastagner A. ${ }^{{ }^{*}}$ chastagner.amelie@gmail.com, Moinet M. ${ }^{\mathrm{b}}$, Perez G. $^{\mathrm{d}, \mathrm{f}}$, Roy E. ${ }^{\mathrm{a}}, \mathrm{McCoy} \mathrm{K.D.}^{\mathrm{c}}$, Plantard 4 O. ${ }^{d, e}$, Agoulon A. ${ }^{d, e}$, Bastian S. ${ }^{d, e}$, Butet A. , Rantier Y. ${ }^{f}$, Verheyden H. ${ }^{g}$, Cèbe N. ${ }^{g}$, Leblond A. ${ }^{\text {a,h }},{ }^{\text {, Vourc'h }}$ $5 \quad \mathrm{G}^{a}$

6

${ }^{a}$ INRA, UR0346 Epidémiologie Animale, F-63122 Saint Genès Champanelle, France

${ }^{\mathrm{b}}$ Anses, Nancy laboratory for rabies and wildlife, Wildlife Surveillance and Ecoepidemiology Unit (SEEpiAS), F54220 Malzéville, France

c UMR 5290 MIVEGEC CNRS-IRD-UM, Centre IRD, F-34394 Montpellier, France

d INRA, UMR1300 Biologie, Epidémiologie et Analyse de Risque en santé animale, CS 40706, F-44307 Nantes, France

e LUNAM Université, Oniris, Ecole nationale vétérinaire, agroalimentaire et de l'alimentation NantesAtlantique, UMR BioEpAR, F-44307 Nantes, France

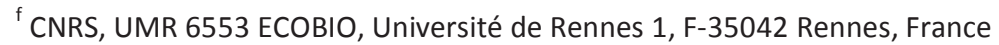

${ }^{\mathrm{g}}$ CEFS, Université de Toulouse, INRA, F-31326 Castanet Tolosan, France

${ }^{\text {h }}$ Département Hippique, VetAgroSup, F-69280 Marcy L'Etoile, France

\section{Abstract}

Anaplasma phagocytophilum is an emerging zoonotic tick-borne pathogen affecting a wide range of mammals. Rodents are suspected to be natural reservoirs for this bacterium, but their role in the epidemiologic cycles affecting domestic animals and wild ungulates has not been demonstrated. This study aimed to improve our knowledge on A. phagocytophilum prevalence in Apodemus sylvaticus, A. flavicollis and Myodes glareolus using data collected in 2010 in one area in eastern France and in 2012-2013 in two others areas in western France. Rodents were captured in each site and infection was tested using qualitative real-time PCR assays on either blood or spleen samples. Prevalence showed high variability among sites. The highest prevalence was observed in the most eastern site (with an average infection rate of $22.8 \%$ across all species), whereas no rodent was found to be PCR positive in the south-west site and only $6.6 \%$ were positive in the north-west of France. Finally, a significant increase in prevalence was observed in autumn samples compared to spring samples in the north-west, but no change was found in the other two sites.

\section{Keywords}

Tick-borne disease; Anaplasma; rodent; prevalence; France 
Introduction

Anaplasma phagocytophilum is an emerging tick-borne disease affecting a wide range of mammals including humans (Stuen, 2007). In Europe, A. phagocytophilum is one of the most important tick-borne bacteria for domestic animals in terms of economic losses (Stuen, 2007), however the factors driving the epidemiologic cycles of this pathogen are largely unknown.

8 Prevalence surveys are the initial tools required to determine which mammalian species are rodents are suspected to act as natural reservoirs for $A$. phagocytophilum (Stuen, 2007). Both groups present high tick burdens and infection prevalence in roe deer can be substantial (up to 90\% positive by PCR (Overzier et al., 2013)). The role of small rodents is not fully understood. Prevalence in rodent populations is sparsely documented in Europe and very variable among species and localities ( $<1 \%$ to 19\%) (Stuen et al., 2013). In Germany and the Czech Republic, the prevalence of infection in Myodes glareolus was similar (around 13\%), whereas, it differed strongly in Apodemus flavicollis, 0.5\% and $15 \%$, respectively, in the two countries (Hulinska et al., 2004; Hartelt et al., 2008). In France, the prevalence of $A$. phagocytophilum in rodents is poorly documented as only one study has been conducted to date, revealing $2 / 18$ positive $A$. sylvaticus from a single location in the north-west of France (Marumoto et al., 2007).

Our objective in this study was to improve our knowledge on $A$. phagocytophilum prevalence in Apodemus sylvaticus, A. flavicollis and $M$. glareolus using data collected from three distinct sites in France where the presence of the bacterium has been previously recorded in ticks or in roe deer.

Materials and methods

Rodents were trapped in three locations across France: one site in north-western France in the “Zone Atelier Armorique” (ZA hereafter, N 48²9'22.40”, W 1³3'41.48”), one site in southwestern France in the region of "Vallons et Coteaux de Gascogne" (VG hereafter, N 4316'2.64", E 051'51.00”), and two sites in eastern France in the Haute-Saône (HS hereafter, N 4740’24.66”, E 642'6.00”').

In ZA and VG, rodents were trapped in the spring and autumn of 2012 and 2013 (4 trap sessions per site). Twenty-four 100-meter traplines of 32 traps each (INRA live traps, fitted with dormitory boxes) were used. Traps were spaced $3 \mathrm{~m}$ apart along the line, with bait, and were checked in the morning 24 and $48 \mathrm{~h}$ after setup. Captured rodents were morphologically identified before being euthanized and autopsied. The spleens were removed and stored at -20 ${ }^{\circ} \mathrm{C}$ for detection of $A$. phagocytophilum. 
1 In HS rodents were captured throughout 2010 during 4 sessions within the framework of a

2 Capture-Mark-Recapture (CMR) survey in two sites, $65 \mathrm{~km}$ apart (Bellevaivre and

3 Chérimont). For each session and site, 49 UGGLAN Special No2 live-traps (Grahnab,

4 Gnosjö, Sweden) were set-up in a 7 x 7 grid of 1 ha $(100 \mathrm{~m} \times 100 \mathrm{~m})$ with approximately 15

$5 \mathrm{~m}$ between traps. Traps were baited and checked over 4 days ( 3 nights). Individuals were

6 marked by toe clipping. Blood sampling was performed on trapped animals using the retro-

7 orbital method. Blood pellets were separated from serum by centrifugation, and stored at -20

$8 \quad{ }^{\circ}$ C. Rodents were morphologically identified and identifications for $A$. sylvaticus and $A$.

9 flavicollis were verified by PCR (Michaux et al., 2001).

DNA in spleen samples were extracted using the kit NucleoSpin Tissue (Macherey Nagel). In the absence of a pre-existing protocol to extract DNA from mammalian blood pellets, we used the "NucleoSpin blood QuickPure" kit and adapted manufacturer instructions by doubling the quantity of proteinase $\mathrm{K}$ and BQ1 during the cell lysis step.

DNA of A. phagocytophilum was detected by real-time PCR targeting the msp2 gene according to the protocol of Courtney et al. (2004).

As individuals from the HS site could be recaptured, we evaluated the independence of the infectious status of recaptured individuals between two successive months using the Pearson correlation test with a confidence interval based on the Fisher z-transformation.

To increase the number of samples per class and test for seasonal differences in prevalence within rodent populations, we also combined some data. For ZA and VG, data from the two years were combined by month (May 2012 with May 2013 and October 2012 with October 2013). For HS, data from the trap sessions in June-July and in September-October were grouped together to determine mean prevalence in summer and autumn, respectively.

The prevalence of $A$. phagocytophilum at each site was analyzed by generalized linear models (GLM) with rodent species and season as explanatory variables. For significant explanatory variables, an odds-ratio was calculated using the exponential of the GLM coefficients and the confidence intervals. A binomial distribution was used to analyze the prevalence in ZA and a quasi-binomial distribution was used for HS to take into account the dispersion of the data.

All statistic analyses were performed using the R statistical software (version 2.15.1).

\section{Results}

In total, 1163 rodents were analyzed including $441 \mathrm{M}$. glareolus, $668 \mathrm{~A}$. sylvaticus and $54 \mathrm{~A}$. flavicollis (Table 1). In HS, 75 individuals were recaptured and tested at least twice for a positive infection. Among these, 13 individuals negative for A. phagocytophilum at first capture became positive the next month, 10 positive individuals recovered from infection, and only 3 remained positive between two successive months. Overall, the infectious status of 
individuals between months was therefore statistically independent $(p=0.59)$. Thus, we considered all captures to be independent for the analyses.

No rodents were found infected by A. phagocytophilum in VG. In HS, prevalence was high $(22.8 \%)$ and stable: no significant difference in prevalence was detected among rodent species $(\mathrm{p}=0.93)$ or among sampling seasons $(\mathrm{p}=0.84)$. In $\mathrm{ZA}$, the prevalence in M. glareolus was significantly higher than in A. sylvaticus ( $\mathrm{p}<0.001, \mathrm{OR}=4.11, \mathrm{CI} 95 \%=[2.09-8.09]$ ) and the prevalence in autumn was significantly higher than in spring $(\mathrm{p}<0.001, \mathrm{OR}=7.35, \mathrm{CI}$ $95 \%=[2.55-21.21])$.

\section{Discussion}

We studied the prevalence of A. phagocytophilum in three rodent species in three sites of France. All species combined, we found a significant difference in prevalence among sites, with a variable pattern of prevalence among rodent species within sites and among seasons.

As in site ZA, higher prevalence of A. phagocytophilum in M. glareolus than in A. sylvaticus has been previously recorded in Switzerland and United Kingdom (Liz et al., 2000; Bown et al., 2003). Although tick infestation rates are generally described to be higher in Apodemus spp. than in M. glareolus (Kurtenbach et al., 1995; Talleklint and Jaenson, 1997; Perez et al, 2016), M. glareolus is considered to be a better reservoir for several tick-borne pathogens (Randolph, 1994; Humair et al., 1999). This interspecific difference could be explained by differences in the ability of their immune systems to eliminate the bacterium. Indeed, Bown et al. (2003) found that M. glareolus was more often positive for A. phagocytophilum over two consecutive months compared to $A$. sylvaticus. Based on this, these authors suggest that a shorter infection time for A. sylvaticus than for M. glareolus may explain lower observed prevalence in the former species. Interspecific differences in local prevalence could also be related to the range of A. phagocytophilum strains infecting each rodent species. For instance, M. glareolus could be infected by a more prevalent strain at the ZA site or be susceptible to more strains than Apodemus spp. Finally, another alternative hypothesis could be related to exploitation by different tick species. Two studies have shown that the endophilic tick $I$. trianguliceps is a more important vector of some A. phagocytophilum strains specific to small mammals than I. ricinus (Blaňarová et al., 2014; Bown et al., 2008). As M. glareolus is frequently more heavily parasitized by this tick species than Apodemus spp. (Gilot et al., 1976), rodent specific exploitation by different tick vectors could explain among-rodent variation in prevalence.

We found that prevalence of A. phagocytophilum increased in autumn in the ZA site, but not in the HS site. A change across seasons could be explained three ways: i) the prevalence of $A$. phagocytophilum in ticks could be higher in autumn, as has been shown in other studies (Bown et al., 2003); ii) the abundance and activity of questing I. ricinus could be higher in late spring-early summer (Schulz et al, 2014; Perez et al, 2016), such that the quantity of ticks encountered by rodents and the probability of infection is greater after this period; and/or iii) the age structure of the rodent population changes such that there are more susceptible 
individuals in autumn. Recruitment in M. glareolus populations begin in June with a peak in autumn (Crawley, 1970). More juvenile rodents are captured during the autumn, and these individuals may not yet have developed resistance to ticks and/or bacteria (Dizij and Kurtenbach, 1995). In HS, rodents were sampled later in the spring than in ZA, such that there were only two months between the two sampling sessions in HS against four months in ZA; this temporal difference could explain the variation found between the two sites. A recent study in Slovakia also found significant seasonal and year-to-year variation in $A$. phagocytophilum prevalence in I. ricinus nymphs, but again this variation was not consistent among sites and was therefore difficult to explain (Svitálková et al., 2015).

The difference in prevalence of $A$. phagocytophilum among areas in France needs further investigation. It cannot be attributed to an artifact linked to the type of biological material tested (blood versus spleen), as earlier studies suggest that bacterial detection may be lower in blood pellets (used in HS) than in the spleen (Liz et al., 2000). Thus, we would therefore expect an underestimation of prevalence in HS compared to the other sites. The site differences could be linked to differences in circulating A. phagocytophilum strains or tick species. However, we could not test this hypothesis in the present study because bacterial loads were too low to enable sequencing and we had only limited information on tick presence on the captured rodents. Nonetheless, we might expect strong differences in the presence and abundance of different tick species among the sampled sites because they lie in different climatic biotopes. Indeed, the VG site lies near the distributional limit for $I$. trianguliceps, potentially explaining the absence of $A$. phagocytophilum in rodents of this zone (Gilot et al, 1976; Pérez-Eid, 2007)

The absence of infection in VG rodents was particularly surprising because approximately $75 \%(56 / 75)$ of roe deer and $2 \%(35 / 1837)$ of questing I. ricinus nymphs have been found positive in this area (Chastagner, 2014). Recent studies in other European countries have shown that rodents and roe deer can carry specific $A$. phagocytophilum lineages, differing from those described in other mammals (Baráková et al., 2014; Majazki et al., 2013). Thus, it could be that no rodent-specific strain of A. phagocytophilum circulates in VG, supporting the hypothesis that rodents do not share the same $A$. phagocytophilum genotypes carried by roe deer. Specific A. phagocytophilum genotypes associated with Ixodes trianguliceps ticks and M. glareolus in Europe (Blaňarová et al., 2014) and with Myodes spp., I. persulcatus and I. trianguliceps in Russia have also been recently described (Rar et al., 2014). Further research is required to investigate the overall diversity and circulation of $A$. phagocytophilum in rodents, especially in Apodemus spp. for which few data are currently available.

Acknowledgments

We thank Axelle Durand, Agnès Bouju-Albert, Emmanuelle Moreau, Olivier Jambon, Elsa Léger, Valérie Noël, Denis Picot, Jean-Michel Demerson, Christophe Caillot, Jacqueline Schaeffer and Franck Boué for collecting the rodent samples; Angélique Pion, Valérie Poux and Sébastien Masséglia were involved in sampling and laboratory work. Séverine Bord and Laurent Crespin helped with data analyses. The coordinators of the Zone Atelier Armorique (Jacques Baudry and Cendrine Mony; http://osur.univ-rennes1.fr/zoneatelier-armorique/) are 
thanked for providing access to the site. Rodent sampling was carried out under the approval of animal ethics committee of Anses/ENVA/UPEC (project number: 12/01/16-1B and $\mathrm{N}^{\circ}$ APAFiS: 2015120215112678) and under the approval of Haute-Garonne ( $\left.{ }^{\circ} 311255504\right)$. Finally, we thank the French National Research Agency, which funded this work through the OSCAR project (ANR-11-AGRO-001-04). (1)

\section{References}

Baráková, I., Derdáková, M., Carpi, G., Rosso, F., Collini, M., Tagliapietra, V., Ramponi, C., Hauffe, H.C., Rizzoli, A., 2014. Genetic and ecologic variability among Anaplasma phagocytophilum strains, northern Italy. Emerg. Infect. Dis. 20, 1082-1084.

Blaňarová, L., Stanko, M., Carpi, G., Miklisová, D., Víchová, B., Mošanský, L., Bona, M., Derdáková, M., 2014. Distinct Anaplasma phagocytophilum genotypes associated with Ixodes trianguliceps ticks and rodents in Central Europe. Ticks Tick-borne Dis. 5, 928-938.

Bown, K. J., Begon, M., Bennett, M., Woldehiwet, Z., Ogden, N. H., 2003. Seasonal dynamics of Anaplasma phagocytophila in a rodent-tick (Ixodes trianguliceps) system, United Kingdom. Emerg. Infect. Dis. 9, 63-70.

Bown, K. J., Lambin, X., Telford, G. R., Ogden, N. H., Telfer, S., Woldehiwet, Z., Birtles, R. J., 2008. Relative importance of Ixodes ricinus and Ixodes trianguliceps as vectors for Anaplasma phagocytophilum and Babesia microti in field vole (Microtus agrestis) populations. Appl. Environ. Microbiol. 74, 7118-7125.

Chastagner, A. P., 2014. Etude des cycles épidémiologiques d'Anaplasma phagocytophilum en France: apport des approches de caractérisation génétique. Thesis: University Blaise Pascal Clermont-Ferrand (France).

Courtney, J. W., Kostelnik, L. M., Zeidner, N. S., Massung, R. F., 2004. Multiplex real-time PCR for detection of Anaplasma phagocytophilum and Borrelia burgdorferi. J. Clin. Microbiol. 42, 3164-3168.

Crawley, M. C., 1970. Some population dynamics of the Bank vole, Clethrionomys glareolus and the Wood mouse, Apodemus sylvaticus in mixed woodland. J. Zool. 160, 71-89.

Dizij, A., Kurtenbach, K., 1995. Clethrionomys glareolus, but not Apodemus flavicollis, acquires resistance to lxodes ricinus L, the main European vector of Borrelia burgdorferi. Parasite Immunol. $17,177-183$.

Gilot, B., Beaucournu, J.C., Pautou, G., Fayard, A., Moncada, E., 1976. Contribution à la connaissance de la répartition et de l'écologie d'Ixodes trianguliceps en France, et plus particulièrement dans le Sud-Est. Acta Trop. 33, 254-286.

Hartelt, K., Pluta, S., Oehme, R., Kimmig, P., 2008. Spread of ticks and tick-borne diseases in Germany due to global warming. Parasitol. Res. 103, 109-116. 
Humair, P. F., Rais, O., Gern, L., 1999. Transmission of Borrelia afzelii from Apodemus mice and Clethrionomys voles to Ixodes ricinus ticks: differential transmission pattern and overwintering maintenance. Parasitol. 118, 33-42.

Kurtenbach, K., Kampen, H., Dizij, A., Arndt, S., Seitz, H. M., Schaible, U. E., Simon, M. M., 1995. Infestation of rodents with larval Ixodes ricinus (Acari: Ixodidae) is an important factor in the transmission cycle of Borrelia burgdorferi sl in German woodlands. J. Med. Entomol. 32, 807-817.

Liz, J. S., Anderes, L., Sumner, J. W., Massung, R. F., Gern, L., Rutti, B., Brossard, M., 2000. PCR detection of granulocytic ehrlichiae in Ixodes ricinus ticks and wild small mammals in western Switzerland. J. Clin. Microbiol. 38, 1002-1007.

Majazki, J., Wüppenhorst, N., Hartelt, K., Birtles, R., von Loewenich, F. D., 2013. Anaplasma phagocytophilum strains from voles and shrews exhibit specific ankA gene sequences. BMC Vet. Res. 9, 235-241.

Marumoto, K., Joncour, G., Lamanda, P., Inokuma, H., Brouqui, P., 2007. Detection of Anaplasma phagocytophilum and Ehrlichia sp. HF strains in Ixodes ricinus ticks in Brittany, France. Clin. Microbiol. Infect. 13, 338-341.

Michaux, J. R., Kinet, S., Filippucci, M. G., Libois, R., Besnard, A., Catzeflis, F., 2001. Molecular identification of three sympatric species of wood mice (Apodemus sylvaticus, A. flavicollis, A. alpicola) in western Europe (Muridae: Rodentia). Mol. Ecol. Notes. 1, 260-263.

Overzier, E., Pfister, K., Herb, I., Mahling, M., Böck, G., Silaghi, C., 2013. Detection of tick-borne pathogens in roe deer (Capreolus capreolus), in questing ticks (Ixodes ricinus), and in ticks infesting roe deer in southern Germany. Ticks Tick-borne Dis. 4, 320-328.

Perez, G., Bastian, S., Agoulon, A., Bouju-Albert, A., Durand, A., Faille, F., Lebert, I., Rantier, Y., Plantard, O., Butet, A., 2016. Effect of landscape features on the relationship between Ixodes ricinus ticks and their small mammal hosts. Parasit.Vectors. 9, 20-39.

Pérez-Eid, C., 2007. Les tiques : identification, biologie, importance médicale et vétérinaire. TEC \& DOC EMinter, Lavoisier, Paris, France, pp. 314.

Randolph, S. E., 1994. Density-dependent acquired resistance to ticks in natural hosts, independent of concurrent infection with Babesia microti. Parasitol. 108, 413-419.

Rar, V. A., Epikhina, T. I., Yakimenko, V. V., Malkova, M. G., Tancev, A. K., Bondarenko, E. I., Ivanov, M. K., Tikunova, N. V., 2014. Genetic variability of Anaplasma phagocytophilum in ticks and voles from Ixodes persulcatus/Ixodes trianguliceps sympatric areas from Western Siberia, Russia. Ticks Tick-borne Dis. 5, 854-863.

Schulz, M., Mahling, M., Pfister, K. (2014). Abundance and seasonal activity of questing Ixodes ricinus ticks in their natural habitats in southern Germany in 2011. J. Vector Ecol. 39, 56-65. 
1 Stuen, S., 2007. Anaplasma phagocytophilum - the most widespread tick-borne infection in animals in

2 Europe. Vet. Res. Commun. 31, 79-84.

3 Stuen, S., Granquist, E. G., Silaghi, C., 2013. Anaplasma phagocytophilum - a widespread multi-host

4 pathogen with highly adaptive strategies. Front. Cell. Infect. Microbiol. 3, 31-71.

5 Svitálková, Z., Haruštiaková, D., Mahríková, L., Berthová, L., Slovák, M., Kocianová, E.,

6 Kazimírová, M., 2015. Anaplasma phagocytophilum prevalence in ticks and rodents in an urban and

7 natural habitat in South-Western Slovakia. Parasit.Vectors. 8, 276-287.

8 Talleklint, L., Jaenson, T. G., 1997. Infestation of mammals by Ixodes ricinus ticks (Acari: Ixodidae)

9 in south-central Sweden. Exp. Appl. Acarol. 21, 755-771.

Table

Table 1. Prevalence of $A$. phagocytophilum detected by real-time PCR (number of positive samples/number of analyzed samples (prevalence \%))

\begin{tabular}{|c|c|c|c|c|c|c|c|c|c|}
\hline & \multicolumn{3}{|c|}{ Zone Atelier Armorique (ZA) } & \multicolumn{3}{|c|}{ Vallons de Gascogne (VG) } & \multicolumn{3}{|c|}{ Haute-Saôr } \\
\hline & May & October & Total & May & October & Total & June & July & Septem \\
\hline \multirow[t]{2}{*}{ M. glareolus } & $3 / 65$ & $17 / 80$ & $20 / 145$ & $0 / 23$ & $0 / 21$ & $0 / 45$ & $13 / 44$ & $24 / 80$ & $12 / 7 !$ \\
\hline & $(4.6)$ & $(21.2)$ & $(13.8)^{\mathrm{a}}$ & (0) & (0) & (0) & $(29.5)$ & $(30)$ & $(15.2$ \\
\hline \multirow[t]{2}{*}{ A. sylvaticus } & $1 / 173$ & $18 / 271$ & $19 / 444$ & $0 / 80$ & $0 / 138$ & $0 / 218$ & & & \\
\hline & $(0.6)$ & (6.6) & $(4.3)^{\mathrm{a}}$ & (0) & (0) & (0) & & $1 / 1(100)$ & - \\
\hline \multirow[t]{2}{*}{ A. flavicollis } & 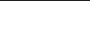 & 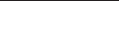 & 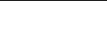 & 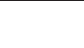 & 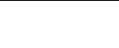 & 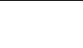 & $1 / 8$ & $2 / 34$ & $6 / 8$ \\
\hline & & & & & & & $(12.5)$ & $(5.9)$ & $(75)$ \\
\hline \multirow[t]{2}{*}{ Total } & $4 / 238$ & $35 / 351$ & $39 / 589$ & $0 / 103$ & $0 / 159$ & $0 / 263$ & $14 / 54$ & $27 / 115$ & $18 / 8^{\prime}$ \\
\hline & $(1.7)^{\mathrm{b}}$ & $(10)^{\mathrm{b}}$ & $(6.6)$ & (0) & $(0)$ & (0) & $(25.9)$ & $(23.5)$ & $(20.7$ \\
\hline
\end{tabular}

GLM results $(\mathrm{OR}=4.11$, CI $95 \%=[2.09-8.09])$. 